\title{
Single-Strand Conformation Polymorphism Analysis by Microchip Electrophoresis for the Rapid Detection of Point Mutation in Human Obesity Gene
}

\author{
Seong Ho Kang, ${ }^{*}$ Sooyoung Jang, ${ }^{4}$ and Sang-Kyu Park \\ Department of Chemistry and Research Institute of Physics and Chemistry (RINPAC), Chonbuk National University, \\ Jeoniu 561-756, Korea. "E-mail: shkang@chonbuk.ac.kr \\ "Korean Minjok Leadership Academy, Anhening 225-823, Korea \\ Received February 28, 2006
}

\begin{abstract}
We describe an effective method of microchip electrophoresis (ME) based on single strand conformation polymorphism (SSCP) analysis to rapidly detect the point mutation. Leu72Met, in a human obesity gene. The 207bp dsDN $\Lambda$ in the Leu72Met region, an estimate of the child obesity DN $\Lambda$ mutant, was amplified by polymerase chain reaction (PCR) and submitted to a conventional glass microchip analysis with a sieving matrix of $1.75 \%$ poly(vinylpyrrolidone) $\left(M_{\mathrm{r}} 1300000\right), 1.0 \%$ poly(ethyleneoxide) $\left(M_{\mathrm{r}} 600000\right)$ and $5.0 \% \mathrm{w} / \mathrm{w}$ glycerol. When combined with base stacking (BS) with hydroxide ions, the SSCP-ME provided rapid analysis as well as sensitive detection. The detection sensitivity was effectively enhanced in the $\mathrm{OII}^{-}$concentration range of 0.01 $0.025 \mathrm{MNaOIL}$. The sensitivity and speed of this ME-based SSCP methodology for the rapid detection of Len72Met point mutations makes this an attractive method for diagnosing childhood obesity in a clinical diagnostic laboratory.
\end{abstract}

Key Words : Microchip electrophoresis, Human obesity diagnosis, Single-strand conformation polymorphism, Point mutation

\section{Introduction}

Ghrelin is a physiological peptide hormone that induces the secretion of somatotrophin (growth hormone, GH), prolactin and adrenocorticotrophin.

It enhances appetite and influences the energy metabolism by decreasing the oxidation of fat. ${ }^{1,2}$ The ghrelin gene resides in the third chromosome long arm (3q25-26), consists of four exons, and encodes 117 amino acids of preproghrelin. The active form of ghrelin is formed at amino acid 28 by octanoylation from preproghrelin. ${ }^{3}$ A mutation in the ghrelin gene was recently reported to be associated with metabolic disorders such as diabetes and obesity. ${ }^{+6}$ This mutation has three single nucleotide polymorphisms, Arg51Gln, Leu72Met and Gly274Ala. Among them, the Leu72Met mutation is most often detected and might be used to predict the coherence transmutation of childhood obesity, because it is found in the early childhood. ${ }^{4}$

Various methods such as anthropometry, ${ }^{7}$ bioelectrical impedance analysis, ${ }^{8-10}$ dual energy x-ray absorptiometry, ${ }^{8.11}$ ultrasound $^{11}$ and skin fold thickness ${ }^{12}$ are employed to diagnose obesity. Although these methods are beneficial to diagnose postnatal diseases, they do not provide the genetic information required to analyze hereditary diseases. The methods used to diagnose postnatal diseases are also unsuitable for diagnosing obesity from the viewpoint of preventive medicine. Among the methods used for the direct detection of gene mutations in preventive medicine, SSCPslab gel electrophoresis is becoming popular on account of its simplicity. Generally, the detection of mutations via conventional SSCP analysis requires PCR amplification of the DNA fragment of interest and denaturation of the double stranded PCR products using heat and formamide, followed by gel electrophoretic separation. The specific DNA fragments stained with silver or ethidium bromide are analyzed using a polyacrylamide TBE gel or an $\mathrm{MDE}^{\mathrm{in}}$ gel. ${ }^{13,14}{ }^{32} \mathrm{P}-$ labeled dNTPs are also incorporated into the PCR products using slab gel electrophoresis in order to increase the detection sensitivity. However, in an attempt to improve the detection efficiency, as well as for greater convenience and safety, many studies have used fluorescent dye-labeled primers or post-fluorescence labeled PCR products instead of the radioactive chemicals in slab gel-based SSCP analysis, ${ }^{15-17}$ capillary electrophoresis (CE)-based SSCP analysis ${ }^{18-25}$ and, more recently, in ME-based SSCP analysis. ${ }^{23}$

Since the first demonstrations of this method by Manz $e t$ $a l^{26}$ and Harrison et $a l .{ }^{27} \mathrm{ME}$ has rapidly become an important technique for identifying DNA fragments on account of its analytical throughput, speed, small reagent volume, automation, miniaturization, high resolution, etc. ${ }^{27-31}$ One of the most important advantages of ME in analyzing DNA fragments is its high speed compared with traditional slab gel electrophoresis and CE. The rapid detection of human obesity DNA was recently demonstrated using a CESSCP method. ${ }^{32}$ In this study, we demonstrate the advantages provided by translating the $\mathrm{CE}$ assay ${ }^{32}$ to the microchip format. The optimization of the ME-based SSCP analysis conditions for the ultra-fast, simple and highly efficiency detection of the Leu72Met point mutation, in order to identify its frequency in children with obesity, is also described. The 207 -bp DNA of the Leu $72 \mathrm{Met}$ region was amplified by PCR. The PCR product was denatured at $95^{\circ} \mathrm{C}$ for $5 \mathrm{~min}$ and snap-cooled on ice. The SSCP profiles for the mutation were obtained in less than $85 \mathrm{~s}$ using ME with BS 
based on gel electrophoretic separation in a polymer network.

\section{Experimental Section}

Materials. Formamide, urea, ethidium bromide (EtBr), nuclease free water, $5 \times$ PCR buffer, GoTaq ${ }^{\mathrm{TM}}$ DNA polymerase and $5 \mathrm{mM}$ dNTP were purchased from Promega (Madison, WI, USA). The $0.5 \times$ TBE buffer $(0.089 \mathrm{M}$ Tris, $0.089 \mathrm{M}$ borate and $0.002 \mathrm{M}$ EDTA, $\mathrm{pH} 8.36$ ) was prepared by dissolving a pre-mixed powder (Amerosco, Solon, $\mathrm{OH}$, USA) in deionized water. The forward primer $\left(5^{\circ}\right.$-AGC AGA GAA AGG AGT CG-3') and the reverse primer (5TGT TCA CTG CCA CCT CT-3') were obtained from GenoTech (Daejeon, Korea). The microchip sieving matrixes, $1300000 M_{F}$ poly(vinyl pyrrolidone) (PVP) and $600000 M_{F}$ poly(ethyleneoxide) (PEO) were purchased from Sigma (St. Louis, MO, USA) and glycerol was acquired from Showa (Japan1). The 100-bp DNA ladder was purchased from Seegene (Seoul, Korea).

Genomic DNA Isolation. The genomic DNA and Leu72Me mutant samples used to identify the child obesity DNA mutant were acquired from the Chonbuk National University Medical School. ${ }^{33}$

Polymerase Chain Reaction. Using the method described in a previous report, ${ }^{32}$ the 207-bp of the Leu72Met region was amplified in a thermal cycler (Perkin-Elmer model 2400 , USA) using the following temperature protocol: $1 \mathrm{~min}$ incubation at $94{ }^{\circ} \mathrm{C} ; 30$ cycles of denaturing at $94^{\circ} \mathrm{C}$ for 60 $\mathrm{s}$, annealing at $56^{\circ} \mathrm{C}$ for $60 \mathrm{~s}$, and extension at $72^{\circ} \mathrm{C}$ for $60 \mathrm{~s}$; followed by $7 \mathrm{~min}$ holding at $72{ }^{\circ} \mathrm{C}$. The $50-\mu \mathrm{L}$ PCR reaction mixture contained the following: $10 \mathrm{~mL}$ each of $10 \times$ PCR buffers 1 and $2,0.5 \mathrm{mM}$ of dNTP, $0.2 \mathrm{pM}$ each of the forward and reverse primers, $1.25 \mathrm{U}^{\mathrm{GoTa}}{ }^{\mathrm{TM}} \mathrm{DNA}$ polymerase, $59.5 \%$ nuclease free water and $3 \mu \mathrm{L}$ of purified DNA. The amplified DNA fragments showed only 207-bp.

Microchip Electrophoresis-Based SSCP Analysis. One microliter of the PCR product (without purification) was combined with $9 \mu \mathrm{L}$ of nuclease free water in a $200 \mu \mathrm{L}$ PCR tube. Unless otherwise specified, the mixture was heated for $5 \mathrm{~min}$ at $95^{\circ} \mathrm{C}$ and snap-cooled on ice for $3 \mathrm{~min}$ before the injection. The SSCP profiles were obtained by introducing the denatured PCR products into the ME system (sample reservoir (2) shown in Figure 1).

ME was performed on a DBCE-100 Microchip CE system (Digital Bio Technology Co., Korea) equipped with a diodepumped solid-state laser (exciting at $532 \mathrm{~nm}$ and collecting fluorescence at $605 \mathrm{~nm}$ ) and a high-voltage device (DBHV100, Digital Bio Technology Co., Korea). The microchip was a standard microfluidic chip (MC-BF4-TT100, Micralyne Inc, USA). The chip channel was $50 \mu \mathrm{m}$ wide and 20 $\mu \mathrm{m}$ deep. The reservoirs were $2.0 \mathrm{~mm}$ in diameter and $1 \mathrm{~mm}$ deep. A double-T injector with a $100 \mathrm{\mu m}$ offset was selected as the conventional microfluidic chip. The injection channel length (from reservoir (2) to reservoir (4) in Figure 1) was $8.0 \mathrm{~mm}$, and the separation channel (from reservoir (1) to reservoir (3) in Figure 1) was $85 \mathrm{~mm}$ long. Detection was

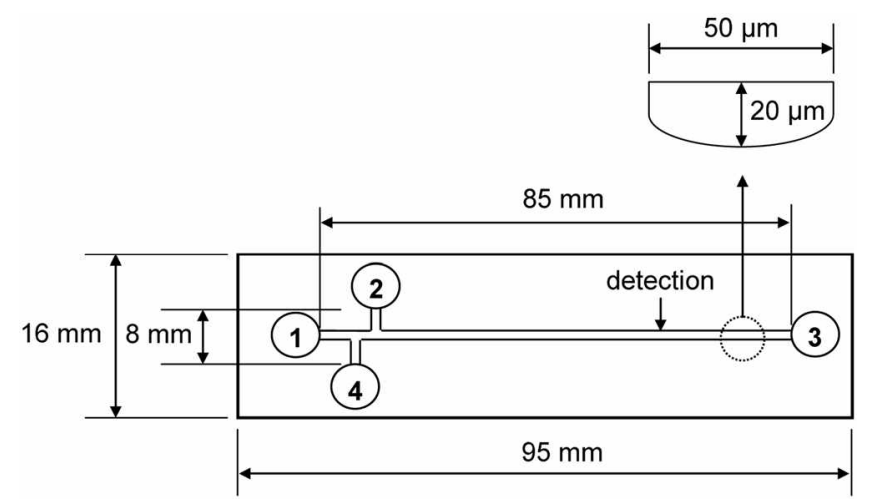

Figure 1. (A) Schematic diagram of the microfluidic chip. Indications: 1,3 : buffer reservoir; $2:$ sample reservoir; $4: \mathrm{NaOH}$ reservoir.

performed at a distance of $65 \mathrm{~mm}$ from the injection-T. The ME sieving matrix was made by dissolving $1.75 \%(\mathrm{w} / \mathrm{v})$ of $\mathrm{I}$ $300000 M_{\mathrm{r}} \mathrm{PVP}$ and $1 \%(\mathrm{w} / \mathrm{v}) 600000 \mathrm{Mr}$ PEO into the $0.5 \times$ TBE buffer ( $\mathrm{pH} 8.36$ ) with $0.5 \mu \mathrm{g} / \mathrm{mL} \mathrm{EtBr}$ and $5 \%$ $\mathrm{w} / \mathrm{w}$ glycerol. Between each run, the microchip channel was re-flushed with water for $4 \mathrm{~min}$ and a sieving matrix for 3 $\min$. The sieving matrix was filled hydrodynamically by applying a vacuum (EYELA A-3S vacuum aspirator, TOKYO RIKAKIKAI Co., Japan) to the ME reservoir (3). The sample was pipetted into the sample inlet reservoir (2) of the microchip. A normal sample was introduced via a conventional electrokinetic injection into the injection-T region by applying $480 \mathrm{~V}$ at the sample outlet reservoir (4) followed by grounding the sample inlet reservoir (2) for 60 $\mathrm{s}$. Separation was achieved by applying $0 \mathrm{~V}$ at the buffer inlet (1) and $+4.25 \mathrm{kV}$ at the buffer waste (3). The peak areas of the DNA fragments were calculated using OriginPro7.5 software (OriginLab Co., Northampton, MA, USA).

Enhancement of the Detection Sensitivity Using Base Stacking. The experimental ME setup and the BS method that was applied were similar to those described elsewhere. ${ }^{34}$ All of the amplified-PCR products were diluted $1 / 10$ for the BS and the conventional electrokinetic injection method was used. The BS procedure was carried out using the following three steps: (1) $\mathrm{OH}^{-}$was injected into the channel $(0.5 \times \mathrm{TBE}$ buffer) using the electrokinetic injection method by applying $480 \mathrm{~V}$ at the 0.01-0.1 M NaOH inlet reservoir (4) and the buffer inlet reservoir (1) was grounded for $20 \mathrm{~s}$, (2) The PCR products were injected into the channel by applying $+480 \mathrm{~V}$ at the sample inlet reservoir (2) and the $\mathrm{NaOH}$ inlet reservoir (4) was grounded for $60 \mathrm{~s}$ (3) The BS and the separation were started by applying $+4.25 \mathrm{kV}$ to the buffer inlet reservoir (1) and the buffer outlet reservoir (3) was grounded. The migration time was measured from this moment for all experiments.

\section{Results and Discussion}

PCR Amplification. The PCR amplification conditions were optimized using the mutant and wild type DNA templates as well as the primers flanking each of the 


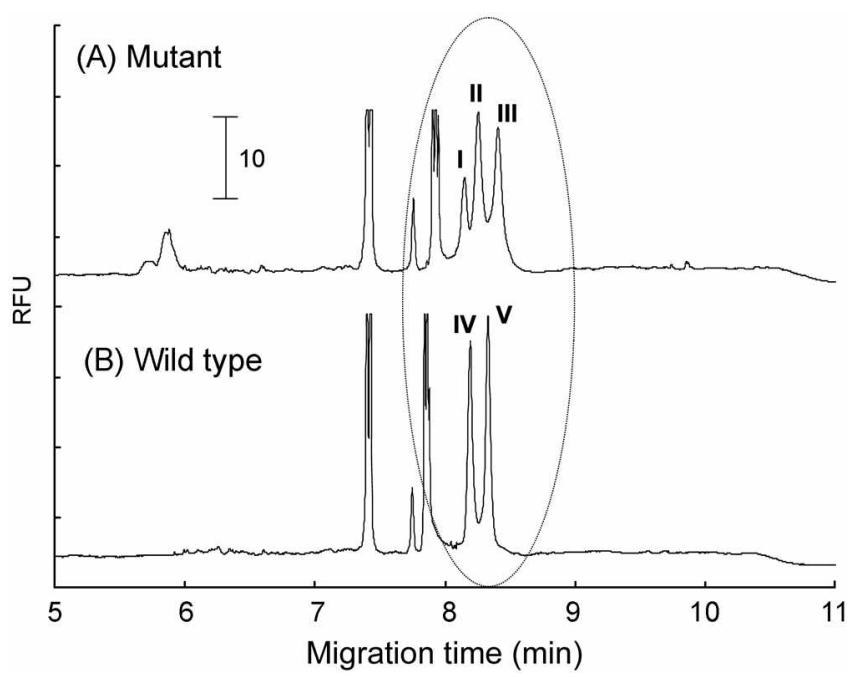

Figure 2. Representative SSCP-CE electropherograns of the mutant $(A)$ and wild type $(B)$ human obesity DN $\Lambda$ under the optinum separation conditions. SSCP-CE conditions: sieving matrix and run buffer, $1.5 \%$ PVT $\left(M_{\mathrm{Y}}, 1300000\right), 1.0 \% \mathrm{PEO}(M, 600000)$ and $5.0 \%$ wt glycerol in $0.5 \times$ TBE buffer with $0.5 \mathrm{ppm} \mathrm{EtBr}$; capillary, $50 \mu$ an I.D $\times 365 \mu \mathrm{m}$ O.D. $\times 60 \mathrm{~cm}$ total length $(30 \mathrm{~cm}$ effective length). The samples were prepared by heating them at $70^{\circ} \mathrm{C}$ for 5 min and then chilling them in an ice bath $\left(1^{\circ} \mathrm{C}\right)$ for $3 \mathrm{~min}$ before injecting the sample into the CE (mixture of nuclease free water $9.0 \mu \mathrm{L}$ and PCR sample $1.0 \mu \mathrm{L}$ ); clectrokinetic injection, $-15 \mathrm{kV}$ for $60 \mathrm{~s}$; applied separation electric field, $375 \mathrm{~V} / \mathrm{cm}$. RFU: Relative fluorescence unit. Indicators: I, II and III = specific peaks of mutant type. IV and $\mathrm{V}=$ specific peaks of wild type (From Kang, S. H.; Jang, S.; Yi, H.-K. J. Korean Chem. Soc. 2005, 49, 537. ${ }^{32}$ ).

mutations. The PCR amplification conditions were optimized using $\mathrm{CE}$ analysis with a laser-induced fluorescence (LIF) detector for the untagged PCR products (207-bp DNA fragment). Because a denaturing step is essential in SSCP analysis, ${ }^{35.36}$ experi-ments were performed to test the effect of the denaturing conditions on the SSCP profiles in the CEbased analysis. The results of the CE-SSCP analysis were the same as those previously reported, ${ }^{32}$ and were analyzed within $9 \mathrm{~min}$ (Figure 2). The potential provided by the SSCP-CE assay was improved by translating it to the microchip format for the ultra-fast detection of the point mutation in the human obesity gene, Leu72Met mutation (207-bp DNA).

Detection Sensitivity Enhancement with Base Stacking. The most significant advantage of ME in DNA analysis is its high speed compared with conventional slab gel electrophoresis and CE. However, although ME has certain advantages over slab gel electrophoresis, the small sample volume imposed by this method is a major limitation, because it results in low concentration sensitivity. The BS technique is generally desirable because making alterations to the microchip design in order to enhance the injection volume and the detection window length can create other problems such as band broadening. ${ }^{3+}$ The BS method was quite simple to perform, because it is only necessary to introduce $\mathrm{OH}^{-}$ions before injecting the DNA sample. The peak height ratios of the DNA fragments increased with increasing $\mathrm{OH}^{-}$concen-
Table 1. Effect of the hydroxide ion $\left(\mathrm{OH}^{-}\right)$concentration on the detection sensitivity of the SSCP analysis by ME with base stacking (BS)

\begin{tabular}{|c|c|c|c|c|c|}
\hline \multicolumn{3}{|c|}{ Mutant } & \multicolumn{3}{|c|}{ Wild type } \\
\hline $\begin{array}{c}\mathrm{NaOH} \\
\text { (M) }\end{array}$ & Peaks & $\begin{array}{l}\text { Peak height } \\
\text { ratio" }\end{array}$ & $\begin{array}{c}\mathrm{NaOH} \\
(\mathrm{M})\end{array}$ & Peaks & $\begin{array}{l}\text { Peak helght } \\
\text { ratio }\end{array}$ \\
\hline \multirow[t]{3}{*}{0} & I & $1: 1$ & 0 & N & $1: 1$ \\
\hline & II & $1: 1$ & & $\mathrm{~V}$ & $1: 1$ \\
\hline & III & $1: 1$ & & & \\
\hline \multirow[t]{3}{*}{0.010} & I & $1: 2.3$ & 0.010 & IV & $1: 5.7$ \\
\hline & II & $1: 5.5$ & & V & $1: 6.7$ \\
\hline & IJI & $1: 8.4$ & & & \\
\hline \multirow[t]{3}{*}{0.025} & J & $1: 2.8$ & 0.025 & IV & $1: 3.6$ \\
\hline & JJ & $1: 5.6$ & & $\mathrm{~V}$ & $1: 7.1$ \\
\hline & IJI & $1: 9.6$ & & & \\
\hline \multirow[t]{3}{*}{0.050} & $\mathrm{I}$ & $1: 2.8$ & 0.050 & IV & $1: 2.8$ \\
\hline & $\mathrm{IJ}$ & $1: 4.2$ & & V & $1: 3.7$ \\
\hline & III & $1: 1.9$ & & & \\
\hline \multirow[t]{3}{*}{0.100} & I & $1: 0.4$ & 0.100 & 厂V & $1: 0.8$ \\
\hline & II & $1: 0.8$ & & $\mathrm{~V}$ & $1: 0.3$ \\
\hline & III & $1: 0.2$ & & & \\
\hline
\end{tabular}

"Peak height ratio: The ratio of the normal peak height-to-peak height with BS. SSCP-BS conditions: microchip, $85 \mathrm{~mm}$ long $\times 50 \mathrm{~mm}$ width $\times$ $20 \mu \mathrm{m}$ depth, effeclive length, $50 \mathrm{~mm}$; sieving matrix and tun buffer, $1.75 \%$ PVP $\left\{M_{r} 1300000 \% 1.0 \%\right.$ PEO $\left(M_{r} 600000\right) / 5.0 \%$ ut glycerol in $0.5 \times$ TBE with $0.5 \mathrm{ppm} \mathrm{EtBr}$; applied electric fields for BS, $533.3 \mathrm{~V} / \mathrm{cm}$ at the gel buffer reservoir 1 and grounding the $0.0(0)-(1.100 \mathrm{M} \mathrm{NaOH}$ reservoir 4 for $20 \mathrm{~s}$; sample injection, $480 \mathrm{~V}$ for $60 \mathrm{~s}$; separation electric field, $500 \mathrm{~V} / \mathrm{cm}$.

tration in the range of $0.01-0.025 \mathrm{M} \mathrm{NaOH}$ (Table 1). However, there was no further signal enhancement in the peak height, but rather a reduction in the resolution, at concentrations higher than $0.05 \mathrm{M} \mathrm{NaOH}$. The overinjection of $\mathrm{OH}^{-}$ions onto the microchip causes rapid neutralization, which can reduce the suppressed electro-osmotic flow. This in turn can trigger the adsorption of DNA molecules onto the inner surface of the microchannel, ${ }^{54}$ which can lead to an abrupt increase in the DNA concentration at the beginning of the peak band with a long tail after the DNA peak. The average calculated signals $(n=5)$ according to the peak height measurements were enhanced 2.8-9.6-fold at an $\mathrm{NaOH}$ concentration of $0.025 \mathrm{M}$ for all SSCP profiles (peaks I-V) in the BS-ME separation compared with those obtained using normal ME (Table 1). However, the resolutions of peaks I-III were better at an $\mathrm{NaOH}$ concentration of $0.05 \mathrm{M}$ than at $0.025 \mathrm{M}$ (data not shown). Enhancing the resolution of the DNA fragments is essential to improve the SSCP analysis by ME. In order to optimize the detection sensitivity and resolution, an injection time of $20 \mathrm{~s}$ and an $\mathrm{NaOH}$ concentration of $0.05 \mathrm{M}$ were selected as the optimum injection time and $\mathrm{OH}^{-}$concentration at a 100 $\mu \mathrm{m}$ offset, double-T microchip and a channel length of 85 mm under an applied electric field of $500 \mathrm{~V} / \mathrm{cm}$ for the SSCP-ME separation with BS.

Optimizing the Conditions for the ME-based SSCP Analysis. The previous SSCP-CE method ${ }^{32}$ was translated 
to the microchip format, wherein the SSCP analysis was completed in several seconds, which nevertheless represents only a fraction of the reduction in the analysis time that can be achieved using microchip technology. The aim of SSCP

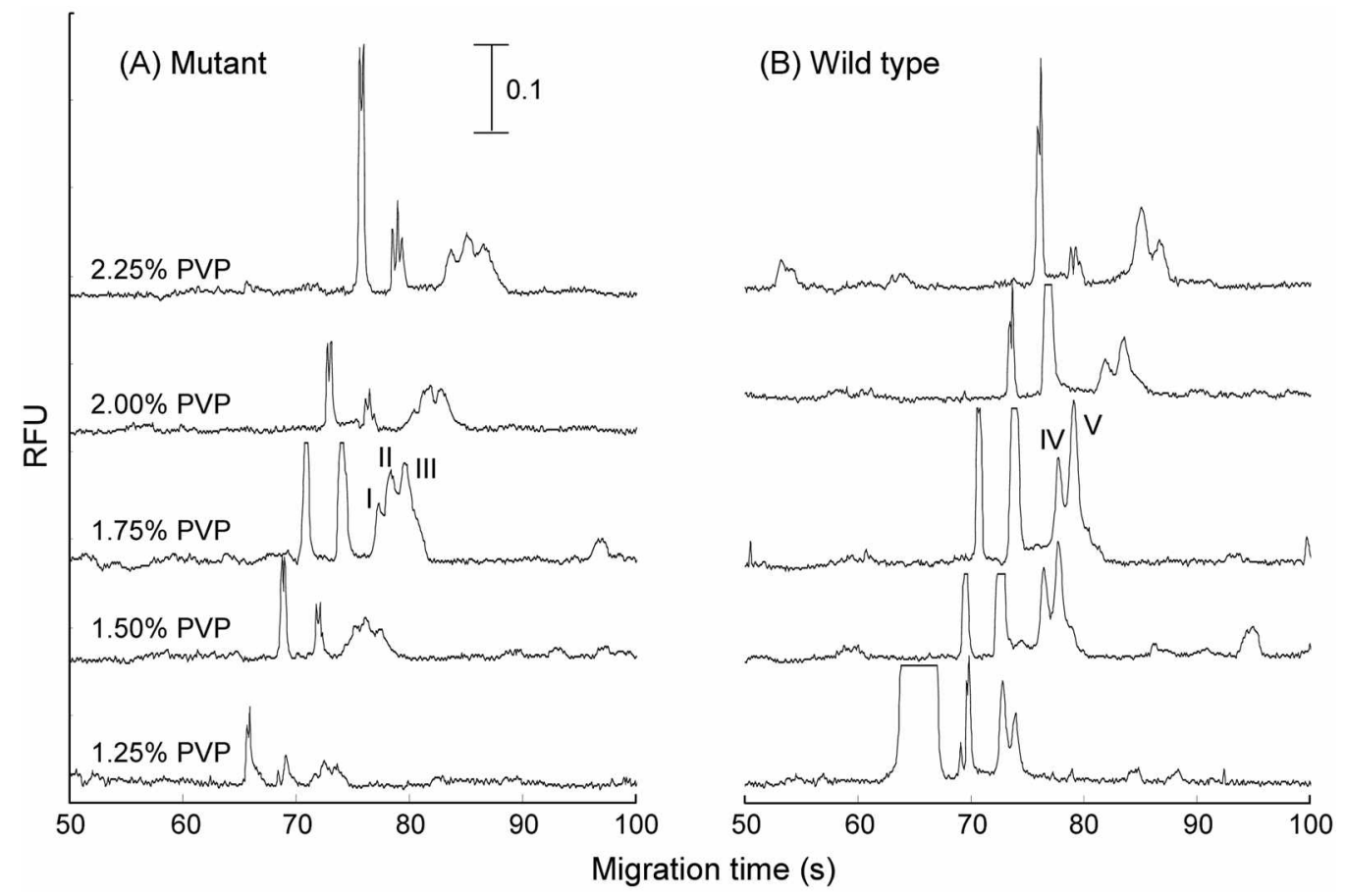

Figure 3. Representative SSCP-ME electropherograms showing the effect of PVP on the resolution. (A) Mutant. (B) Wild type. SSCP-ME conditions: microchip, $85 \mu \mathrm{m}$ long $\times 50 \mu \mathrm{an}$ width $\times 20 \mathrm{~mm}$ depth, effective length, $50 \mathrm{~mm}$; sieving inatrix and run buffer, $1.25-2.25 \%$ PVP $\left(M_{\mathrm{r}}\right.$ I 300000$), 1.0 \%$ PEO $\left(M_{\mathrm{r}} 600000\right)$ and $5.0 \%$ wt glycerol in $0.5 \times$ TBE with $0.5 \mathrm{ppm}$ EtBr. The samples were diluted with $9.0 \mu \mathrm{L}$ of muclease free water, and $1.0 \mu \mathrm{L}$ of each PCR sample was placed into a $200 \mu \mathrm{L}$ PCR tube. The samples were heated at $95^{\circ} \mathrm{C}$ for $5 \mathrm{~min}$ and cooled on ice $\left(1{ }^{\circ} \mathrm{C}\right)$ for $3 \mathrm{~min}$ before the injection. $533.3 \mathrm{~V} / \mathrm{cm}$ was applied to the gel buffer reservoir (1) and the $0.025 \mathrm{M} \mathrm{NaOH}$ reservoir (4) was grounded for $20 \mathrm{~s}$; sample injection, elcetrokinctic injection, $500 \mathrm{~V} / \mathrm{cm}$ for $60 \mathrm{~s}$; separation elcctric field, $500 \mathrm{~V} / \mathrm{cm}$. RFU: Relative fluoresecnec unit. Indicators: I, II and III = specific peaks of imutant type. IV and V = specific peaks of wild type.

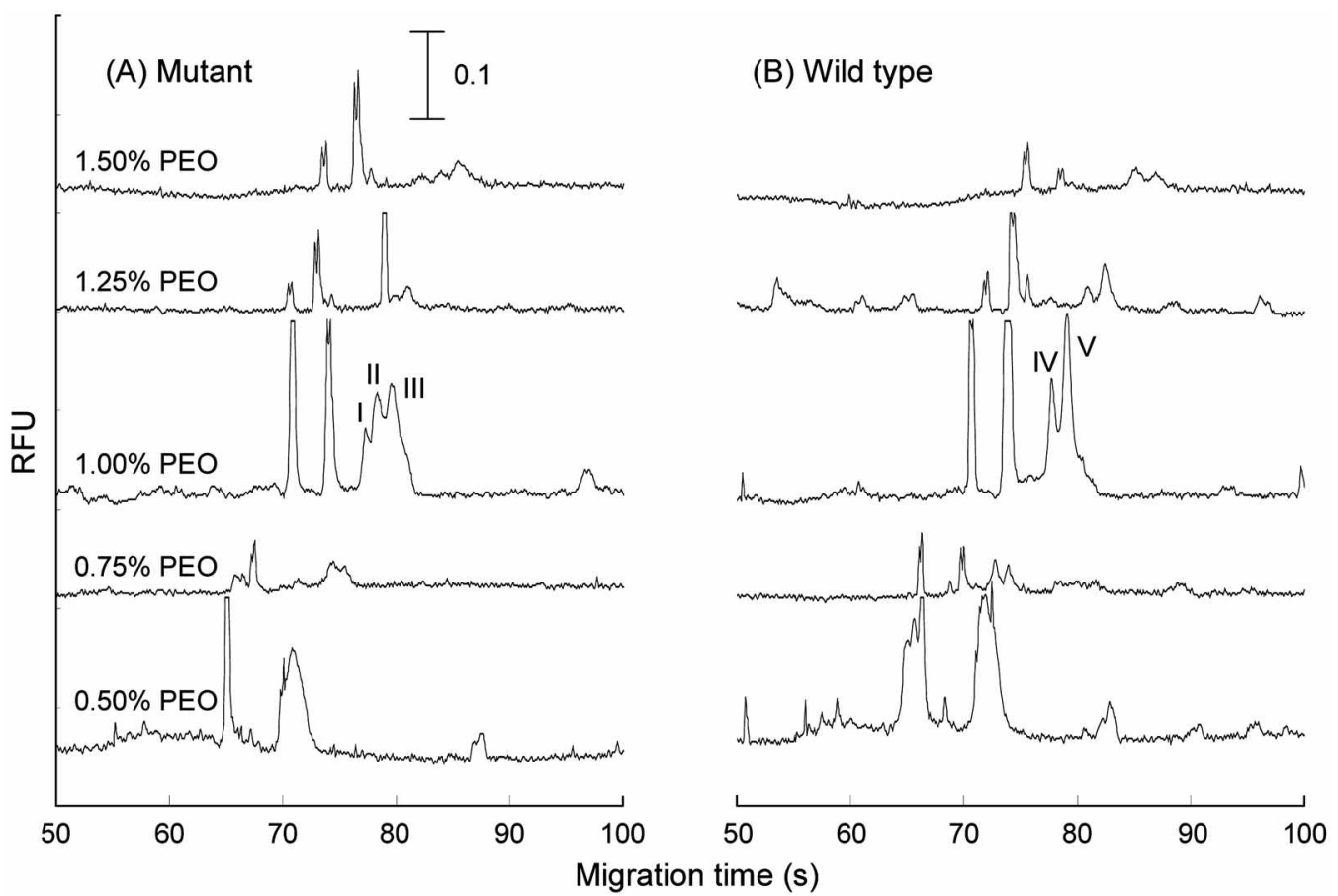

Figure 4. Effect of PEO on the resolution of the SSCP analysis by ME with base stacking. $(A)$ Mutant. (B) Wild type. Sieving inatrix and run buffer, $1.75 \%$ PVP $\left(M_{\mathrm{r}} 1300000\right), 0.50-1.50 \%$ PEO $\left(M_{\mathrm{r}} 600000\right)$ and $5.0 \%$ wt glycerol in $0.5 \times$ TBE with $0.5 \mathrm{ppm}$ EtBr. The other SSCP-ME conditions were the same as those described in Figure 3. 
analysis by ME is to separate the sSDNA fragments (wild type and mutant) rapidly according to their conformations under native conditions. Conventional SSCP analysis involves polyacrylamide slab-gel electrophoresis in the presence of neutral additives, such as glycerol, urea, ethylene glycol, formamide, and sucrose, which are used to improve the resolution. ${ }^{37}$ It is important to test the effect of each additive on the resolution when using ME-based SSCP, where various linear polymer solutions in the microchip are used for size-based DNA fragment separation, instead of using polyacrylamide gel. Therefore, in this study, we evaluated the effect of various additives on the rapid detection of the Leu72Met point mutation using SSCP-ME analysis, by varying the glycerol concentration and the electric field in solutions of polymers such as PVP and PEO.

Single-stand DNA (ssDNA) fragments, which are different from the original DNA fragments, were prepared in order to determine the SSCP profiles by directly immersing the original DNA fragments in a $1^{\circ} \mathrm{C}$ ice bath after denaturing the amplified 207-bp human obesity double-strand DNA (dsDNA) sample at $95{ }^{\circ} \mathrm{C}$. The neutral additives did not affect the detection or resolution of the ssDNA fragments (data not shown). Figures 3 and 4 show the effects of the PVP and PEO concentrations on the SSCP profiles of the amplified 207-bp DNA fragments, respectively. PVP and PEO were used as a sieving matrix for analyzing the PCRamplified DNA containing the Leu72Met point mutation. Although the mutant and wild type ssDNA fragments were not resolved with the baseline, the SSCP profiles of the Leu72Met point mutation could be analyzed without difficulty using $1.75 \% \mathrm{PVP}$ and $1 \% \mathrm{PEO}$ in the sieving matrix and separation buffer solution, respectively.

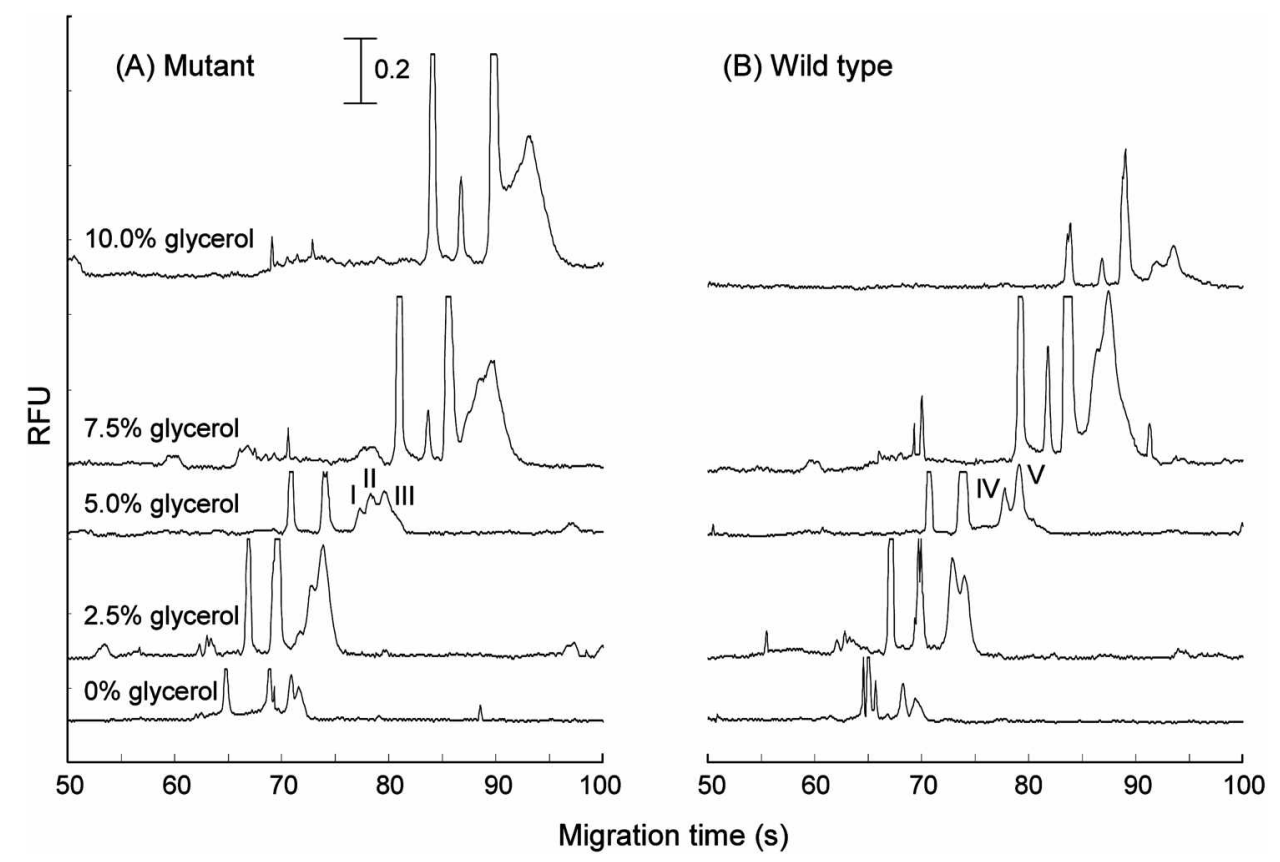

Figure 5. Effect of glycerol on the resolution of the SSCP analysis by ME with base stacking. (A) Mutant. (B) Wild type. SSCP-ME conditions: sieving matrix and run buffer, $1.75 \% \mathrm{PVP}\left(M_{\mathrm{J}}, 1300000\right), 1.0 \% \mathrm{PEO}\left(M_{\mathrm{T}} 600000\right)$ and $0.0-10.0 \%$ wt glycerol in $0.5 \times \mathrm{TBE}$ with $0.5 \mathrm{ppm}$ EtBr. The other SSCP-ME conditions were the same as those described in Figure 3.
Table 2. Effect of the glycerol concentration on the resolution of the SSCP-ME analysis with base stacking

\begin{tabular}{|c|c|c|c|c|c|c|c|}
\hline \multicolumn{4}{|c|}{ Mutant } & \multicolumn{4}{|c|}{ Wild type } \\
\hline $\begin{array}{c}\text { Glycerol } \\
(\%)\end{array}$ & Teaks & $\begin{array}{l}\text { Migration } \\
\text { time (s) }\end{array}$ & $R_{s}$ & $\begin{array}{c}\text { Glycero } \\
(\%)\end{array}$ & Peals & $\begin{array}{c}\text { Migration } \\
\text { tume (s) }\end{array}$ & $R_{\mathrm{s}}$ \\
\hline 0.0 & $\begin{array}{l}\text { I } \\
\text { II } \\
\text { III }\end{array}$ & $\begin{array}{c}- \\
70.938 \\
71.594\end{array}$ & $\overline{0.345}$ & 0.0 & $\begin{array}{l}\mathrm{JV} \\
\mathrm{V}\end{array}$ & $\begin{array}{l}68.313 \\
69.406\end{array}$ & 0.607 \\
\hline 2.5 & $\begin{array}{l}\text { I } \\
\text { II } \\
\text { III }\end{array}$ & $\begin{array}{l}71.813 \\
72.907 \\
73.089\end{array}$ & $\begin{array}{l}0.447 \\
0.058\end{array}$ & 2.5 & $\begin{array}{l}\text { IV } \\
\mathrm{V}\end{array}$ & $\begin{array}{l}72.906 \\
74.000\end{array}$ & 0.377 \\
\hline 5.0 & $\begin{array}{l}\text { I } \\
\text { II } \\
\text { III }\end{array}$ & $\begin{array}{l}77.218 \\
78.375 \\
79.687\end{array}$ & $\begin{array}{l}0.538 \\
0.495\end{array}$ & 5.0 & $\begin{array}{l}\text { JV } \\
\mathrm{V}\end{array}$ & $\begin{array}{l}77.828 \\
79.140\end{array}$ & 0.656 \\
\hline 7.5 & $\begin{array}{c}\text { I } \\
\text { II } \\
\text { III }\end{array}$ & $\begin{array}{l}87.453 \\
88.657 \\
89.641\end{array}$ & $\begin{array}{l}0.339 \\
0.216\end{array}$ & 7.5 & $\begin{array}{l}\text { IV } \\
\text { V }\end{array}$ & $\begin{array}{l}86.469 \\
87.453\end{array}$ & 0.243 \\
\hline 10.0 & $\begin{array}{c}\text { I } \\
\text { II } \\
\text { III }\end{array}$ & $\begin{array}{c}- \\
- \\
93.250\end{array}$ & - & 10.0 & $\begin{array}{l}\text { IV } \\
\mathrm{V}\end{array}$ & $\begin{array}{l}92.047 \\
93.395\end{array}$ & 0.345 \\
\hline
\end{tabular}

SSCP-BS conditions: sieving matrix and run buffer, $1.75 \%$ PVP $\left\{M_{\mathrm{r}} 1\right.$ $300000), 1.0 \%$ PEO $\left(M_{\mathrm{r}} 600000\right)$ and $0.0-10.0 \%$ ut glycerol in $0.5 \times$ TBE with $0.5 \mathrm{ppm}$ EtBr. The other conditions were the same as those described in Táble 1 .

The effect of varying the glycerol concentration in the mixed polymer solution containing $1.75 \%$ PVP $\left(M_{\mathrm{r}} \mathrm{I} 300\right.$ $000)$ and $1.0 \%$ PEO (Af 600000$)$ on the detection of the ssDNA fragments and their resolution by ME-based SSCP was also evaluated (Figure 5). Vidal-Puig et al. tested large-
(B) Wild type 


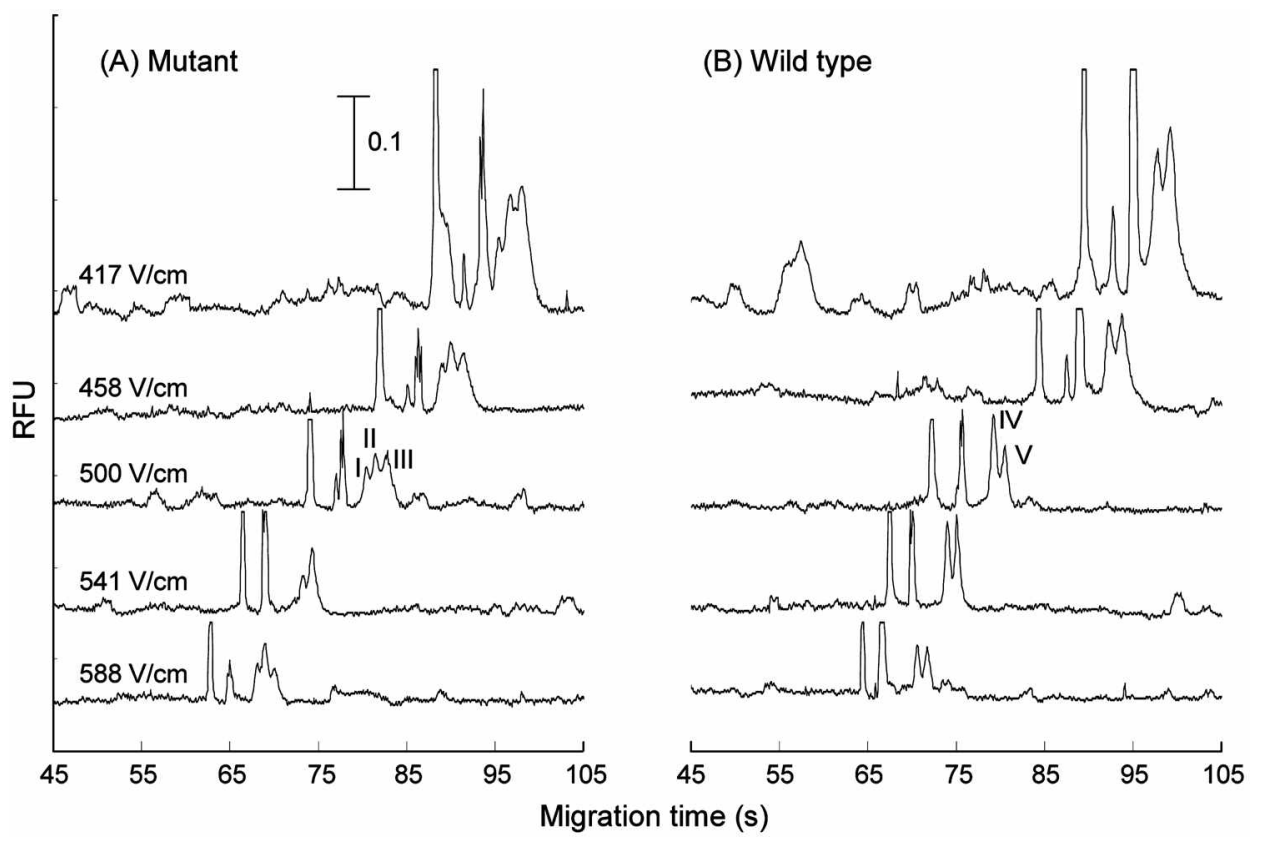

Figure 6. Representative SSCP-ME electropherograms showing the effect of the electric field. (A) Mutant. (B) Wild type. SSCP-ME conditions: separation electric field, 417-588 V/cm. The other SSCP-ME conditions were the same as those described in Figure 3.

format gels ( $5 \%$ polyacrylamide and Hydrolink-MDE ${ }^{\mathrm{TM}}$ ) with and without $10 \%$ glycerol in the SSCP analysis of 19 known human mutations. ${ }^{38}$ They reported that all of these mutations could be detected with either polyacrylamide or Hydrolink - MDE $^{\mathrm{TM}}$ (AT Biochem, Malven, PA, USA), regardless of whether or not glycerol was used in the SSCP analysis. The present study also found that glycerol did not affect the detection sensitivity in the SSCP analysis of the Leu72Met mutation. However, the use of glycerol improved the resolution of the SSCP peaks (Table 2). The presence of $2.5 \%$ glycerol in the sieving matrix and separation buffer solution was found to be beneficial for improving the resolution of both the mutant and wild type ssDNA fragments. The use of $5.0 \%$ glycerol was found to be optimal for both types with a separation time of less than 85 $\mathrm{s}$, as shown in Figure 5.

Because the ultimate goal was to use SSCP analysis by CE to detect point mutations on an electrophoretic microchip, the differences between the two platforms need to be considered. On the other hand, the separation of DNA fragments by ME in a mixture matrix containing PVP and PEO is mainly affected by the electric field strength. ${ }^{39}$ The SSCP-ME results were examined after injecting the PCRamplified products (ssDNA fragments) from the Leu72Met point mutation directly without purification at electric field strengths ranging from 417 to $588 \mathrm{~V} / \mathrm{cm}$. The velocity of the DNA fragments increased and the migration time decreased with increasing electric field strength, which lead to shorter analysis times (Figure 6). However, higher voltages cause higher currents and, thus, more Joule heating. Increased heat in a microchip can lead to non-reproducible migration times, decomposition of the ssDNA fragments, and even boiling of the buffer, which will definitely decrease the resolution and efficiency. The SSCP peaks were easily analyzed within $85 \mathrm{~s}$ under a constant electric field strength of $500 \mathrm{~V} / \mathrm{cm}$ (Figure 6 middle) and showed resolutions $\left(R_{\mathrm{s}}\right)$ of 0.423 (I and II), 0.515 (II and III) and 0.625 (IV and V).

\section{Conclusion}

The efficiency of SSCP-ME analysis with BS in the rapid detection of single base substitutions was tested on a point mutation in a human obesity gene, Leu72Met. The detection sensitivity was enhanced 2.8-9.6-fold when using an $\mathrm{NaOH}$ concentration of $0.025 \mathrm{M}$. However, $0.05 \mathrm{M} \mathrm{NaOH}$ was selected as the optimum concentration in the ME analysis with $\mathrm{BS}$, because of the higher resolution and detection sensitivity that this afforded. Neutral additives such as urea and formamide had little or no effect on the detection and resolution of the SSCP peaks in the ME separation. The SSCP profiles were obtained in less than $85 \mathrm{~s}$ using ME with BS in a microchip with a sieving matrix consisting of $1.75 \%$ PVP, $1.0 \% \mathrm{PEO}$ and $5.0 \% \mathrm{w} / \mathrm{w}$ glycerol, which resulted in a 10-70 times faster analysis time than that obtained in conventional $\mathrm{CE}$ and slab gel electrophoresis. The simplicity and speed of the ME-based SSCP methodology with BS for the rapid detection of Leu72Met point mutations makes this technique attractive for diagnosing childhood obesity in a clinical diagnostic laboratory.

Acknowledgement. The authors wish to thank Dr. H.-K. Yi at Chonbuk National University for providing the samples and Digital Bio Technology for supplying the ME system. This work was supported by a grant from the Korea Ministry of Science and Technology (M10536080003$05 \mathrm{~N} 3608-00310$ ). 


\section{References}

1. Kojima, M.; Hosoda. H.; Date, Y.; Nakazato, M.; Matsuo, H.; Kangawa, K. Nature 1999, 402,656.

2. Date, Y.; Kojima, M.; Hosoda, H.; Sawaguchi, A.; Mondal, M. S.; Suganuma, T; Matsukura, S.; Kangawa, K.; Nakazato, M. Endocrinology 2000, 141,4255 .

3. Wajnrạich, M. P.; Ten, I. S.; Heiman, M. L. J. Endo. Gen. 2000, $I$, 231

4. Ukkola, O.; Ravussin, E.; Jacobson, P.; Snyder, E. E.; Chagnon, M.; Sjostrom, L.; Bouchard, C.J. Clin. Endocrinol. Metab. 2001, $86,3996$.

5. Korbonits, M.; Gueorguiev, M.; OGrady, E.; Lecoeur, C.; Swan, D. C.; Mein, C. A.; Weill, J.; Grossman, A. B.; Froguel, P. J. Clin. Endocrinol. Metah. 2002, 87, 4005.

6. Poykkkö, S.; Ukkola, O.; Kauma, H.; Savolainen, M. J.; Kesäniemi, Y, A. Diabetologia $\mathbf{2 0 0 3}, 46,455$

7. Kim, M.-G; Kim, C.-K. Korean J. Phy. Edh. 2001, 40, 559.

8. Cho, Y. H.; Choi, S. K.; Kim, D. Y.; Woo, J. T.; Kim, S. W.; Yang, I. M.; Kim. J. W.; Choi, Y. K. Korean Soc. Stuty Obesity 1997, 6, 59.

9. Nunez, C.; Gallagher, D.; Visser, M.; Pi-Sunyer, F. X.; Wang. Z.; Heymsfield, S. B. Med. Sci. Sports Exerc. 1997, 29, 524.

10. Heymsfield, S. B.; Wang, Z,; Visser, M.; Gallagher, D.; Pierson, R. N. Jr. Am. J. Clin. Nutr, 1996, 64,478S.

II. Lukaski, H. C. Ant. J. Clin. Nitr. 1987, 46, 537.

12. Moreno, L. A.; Leün, J. F.; Serün, R.; Mesana, M. I.; Fleta, J. Nutr. Res. 2004, 24. 235 .

13. Devauchelle, V.; Chiochia, G Rev, Med. Interne 2004, 25, 732.

14. Zimmermann, M. B.; Gubeli, C.; Puntener, C.; Molinari, L. Swiss Med. Wkity: 2004, $134,523$.

15. Jwahana, H.; Adzuma, K.; Takahashi, Y.; Katashima, R.; Yoshimoto, K.; Itakura, M. PCR Methods Appl. 1995, 4, 275.

16. Jwahana, H.; Fujimura, M.; Takahashi, Y.; Iwabuchi, T.; Yoshimoto, K.; Itakura, M. Biotechniques 1996, 21, 510.

17. Jwahana, H.; Yoshimolo, K.; Mizusawa, N.; Kudo, E.; Itakura, M. Biotechingues 1994, 16, 296.

18. Atha, D. H.; Wenz, H. M.; Morehead, H.; Tian, J.; O'Connell, C. D. Electrophoresis 1998, 19, 172.

19. Inazuka, M.; Wenz, H.-M.; Sakabe, M.; Tahira. T.; Hayashi, K.
Genome Res. 1997, 7, 1094.

20. Larsen, L. A.; Christiansen, M.; Vuust, J.; Andersen, P. S. Hum. Mutat. 1999, 13, 318 .

2l. Wenz, H. M.; Baumhueter, S.; Ramachandra, S.; Worwood, M. Hum. Genet, 1999, 104, 29.

22. Ren, J.; Ulvik, A.; Ueland, P. M.; Refsum, H. Anal, Biochem. $1997,245,79$

23. Tian, H.; Jaquins-Gerstl, A.; Munro, N. J.; Trueco, M.; Brody, L. C.: Landers, J. P. Genomics 2000, 63, 25.

24. Ozawa, S.; Sugano, K.; Sonehara, T.; Fukuzono, S.; Ichikawa, A.; Fukayama, N.; Taylor, M.; Miyahara, Y.; Irie, T, Anal. Chem. $2004,76,6122$.

25. Kuhn, D. N.; Borrone, J.; Meerow, A. W.; Molamayor, J. C.; Brown, J. S.; Schnell, R. J. Electrophoresis 2005, 26, 112.

26. Manz. A.; Graber, N.; Widmer, H. M. Sents. Actuators 1990, BI, 24.

27. Harrison, D. J.; Manz, A.; Fan, Z.; Ludi, H.; Widmer, H. M. Anal. Chem. 1992, 64, 1926.

28. Zhang. L.; Dang, F.; Baba, Y. J. Pharm. Biomed. Aftal. 2003, 30, 1645 .

29. Woolley, A. T.; Mathies, R. A. Anal. Chem 1995, 67, 3676.

30. Schmalzing, D.; Adourian, A.; Koutny, L.; Ziaugra, L.; Matsudaria, P; Ehrlich, D. Anal. Chem. 1998, 70, 2303.

3l. Backhouse, C.; Caamano, M.; Oaks, F.; Nordman, E.; Carrillo, A.; Johnson, B.; Bay, S. Electrophoresis 2000, 21, 150.

32. Kang. S. H.; Jang, S.; Yi, H.-K. J. Korean Chem. Soc. 2005, 49. 537.

33. Jo, D. S.; Lee, J. U.; Kim, S. Y.; Kim, S. J.; Kang, C. W.; Hwang, P. H.; Lee, D. Y, J. Kor: Soc. Ped. Endocrinol. 2004, 9, 179.

34. Kim, D. K.; Kang S. H. J. Chromatogr: A 2005, 1064, 121 ,

35. Hayshi, K.; Kukita, Y,; Inazuka, M.; Tahira, T. In Mutation Detection: A Practical Approach; Cotton, R. G. H.; Edkins, E.; Forrest, S., Eds.; Oxford Univ. Press: New York, U.S.A., 1998; p 7.

36. Humphires, S. E.; Gudnason, V; Whittall, R. E.; Day, I. N. In Molecular Diagnosis of Genetic Disenses; Elles, R, Eds.; Humana Press: Totowa, NJ., U.S.A., 1996; p 321.

37. Tian, H.; Brody, L. C.; Landers, J. P. Genone Res. 2000, J0, 1403.

38. Vidal-Puig, A.; Moller, D. E. Biotechnigues 1994, $77,490$.

39. Kang. S. H.; Park, M.; Cho. K. Electrophoresis 2005, 26, 3179. 